\title{
Extensions of Time and Conditions of Notice: California's Needless Restriction of Contractual Freedom
}

\author{
Justin Sweet*
}

\begin{abstract}
AMOST UNIVERSALIY, building contracts contain a provision that con$A$ ditions the contractor's right to claim an extension of time for delays beyond his control upon giving written notice of his intention to make such a claim. ${ }^{1}$ Despite contrary precedents, ${ }^{2}$ a unanimous California Supreme Court gutted this sensible provision in Kiewit v. Pasadena School District. $^{3}$ A questionable application of an obscure provision of California Civil Code Section 1511 was employed to justify the court's refusal to give effect to this express condition. This decision will undoubtedly hamper fair and effective administration of California construction contracts and should not pass unnoticed by the Bar.

The contract in the Kiewit case dealt with the construction of school facilities for over one million dollars. The contractor did not coniplete
\end{abstract}

* B.A., University of Wisconsin, 1951; LL.B., University of Wisconsin, 1953; Professor of Law, University of California School of Law, Berkeley.

I See American Institute of Architects, Standafo Contract, art. 18, Doc. No. A-201 (1961), which states that "[N]o such extension [of time] shall be made for delay occurring more than seven days before claim therefore is made in writing to the Architect.". A typical state public contract provision grants an extension only if "the contractor shall notify the Engineer in writing of the causes of the delay within 15 days from the beginning of any such delay." State of Calffornta, Departament of Public Works, Division of Highways, StandARD Specifications $\$ 8.107$ (1960). In Federal construction contract procurement, the contractor must give notice within 10 days of the delay unless given additional time by the contracting officer. Armed Services Procurement Regulations, 32 C.F.R. 8 8.709(d) (2) (1962).

2 Roberts v. Sec. Trust \& Sav. Bank, 196 Cal. 557, 238 Pac. 673 (1925); Suhr v. Metcalfe, 33 Cal. App. 59, 164 Pac. 407 (1917). Roberts fell by the wayside because $\S 1511$ of the Civil Code, the section reked upon by Kiewit, had not been mentioned and because the architect had made a factual determination that the delay was not justified. Suhr was swept aside because although it had mentioned $\S 1511$, the decision, according to the Kiewil court, "erroneously concluded, without analysis or citation of authority, that the section was not applicable to acts of an owner causing late completion of a construction contract." 59 A.C. at 256, 379 P.2d at 20, $28 \mathrm{Cal}$. Rptr. at 716. In Suhr the court stated: "We can see no reason why it was not conipetent for the parties to provide in their contract for an exclusive method by which the time could be extended as to this particular feature, nor do we see anything in the way of giving effect to such agreement." 33 Cal. App. at 69, 164 Pac. at 411 . This case was cited by a California encyclopedia as precedent for giving effect to the notice requirement. 12 CarIFORNIA JURISPRUdENCE 2d, Contracts, § 228 (1953).

359 A.C. 253, 379 P.2d 18, 28 Cal. Rptr. 714 (1963). 
performance on time, and the School District witheld part of the retainage as liquidated damages for the delay. The contractor claimed that the delay was caused by acts of the School District, ${ }^{4}$ and by other events over which he had no control. An express provision of the contract required that written notice of an intention to claim an extension of time be given the School District within ten days after the incident causing the delay.

In the trial court the School District proved a failure on the part of the contractor to give the required notice. The trial court found that the delays were caused by the School District, and held that the notice provision was waived and no liquidated damages were due. ${ }^{5}$

The district court of appeals affirmed the trial court, employing a rule of law-the "nonapportionment" rule-that enabled it to bypass the notice question. ${ }^{6}$ Under this rule, if both parties have contributed to the delay, a court will not apportion responsibility for delay, and will not enforce a provision liquidating damages. The rule is not applied, however, if the parties by contract provide for a method of apportionment. ${ }^{7}$ As for the notice requirement, it appears the court felt that notice was not necessary where the owner caused the delay. The court's reasoning is difficult to follow, ${ }^{8}$ but in

4 Examples of what the contractor contended excused his obligation to finish the work by the completion date were: (1) errors, conflicts and omissions in the School District's interpretations of the plans, (2) frequent revisions, and (3) unreasonably long periods to approve change orders. These facts are found in the opinion of the district court of appeals. Kiewit v. Pasadena School Dist., 22 Cal. Rptr. 589, 592-93 (1962).

5 The waiver was based upon: (1) requests for revised work without suggesting the necessity of making written applications for time extensions, (2) granting time extensions without prior written applications, (3) representations that if contractor would proceed extensions would be granted at a later time, and (4) after completion that the parties would agree on a true completion date. Kiewit v. Pasadena School Dist., supra note 4 at 593.

6 Id. at 591-92.

75 WIIISTON, Contracts 764 (3d ed. 1961). In the typical building contract this is accomplished by a provision giving the architect the power to determine whether the contractor's delay is excused and, if so, the duration of the extension to be granted.

8 The somewhat involuted language of the opinion was as follows:

We find it unnecessary to extend this opinion by a discussion of this contention [excuse of the contractor]. While conceding there was substantial evidence that its own acts and omissions delayed the work for at least 3 months, defendant said: “. . the contractor was and is precluded from relying upon delays allegedly caused by the district where the contractor failed to make a written request for an extension of time within 10 days of the occurrence of such delays . ..."

It is then contended that findings that the plaintiff was not at fault in the matter of requesting extensions of time were without support in the evidence. This argument is made solely in support of the claim for liquidated damages. It has no relevance to the matter of the delays for which defendant was responsible and hence is not a matter to be considered in application of the rule that the detriment occasioned by delay cannot be apportioned when both parties are at fault. It is irrelevant to the claim for liquidated damages. The failure of plaintiff to justify or excuse its delay in all respects would mean only that it did not complete the work within the agreed time. Its failure to obtain extensions of time, if there was such a failure, 
any event the absence of notice did not preclude Kiewit from recovering.

Both the waiver and the nonapportionment approaches had legally awkward aspects. In private contracts many cases have held that the architect has no authority to waive the notice provision. ${ }^{10}$ This problem is accentuated when the owner is a public body and public rights and funds are involved. The law has been reluctant to permit public officials and employees to waive protective provisions. 11 The problems of applying the "nonapportionment" rule stem from Gogo v. Los Angeles Flood Control District. ${ }^{12}$ Gogo involved a contract containing a provision for apportioning responsibility for delays through granting extensions. This provision, however, was not mentioned by the court in Gogo. The briefs submitted to the district court of appeals in Kiewit clashed over whether this omission in the opinion meant that Gogo should not control where the contract in question $d i d$ contain a provision for extensions of time. ${ }^{13}$ The district court of appeals refused to limit Gogo solely to contracts that did not contain a provision for apportionment of responsibility for delays.

Notwithstanding the awkward aspects of these theories, without one of them it appeared that the supreme court would be faced with a situation in which a failure to comply with a "techmicality" would permit the School District to collect damages for a delay which, at least in the view of the trial court, was caused by the School District. The supreme court, however, found a solution without reference to the troublesome theories of the courts below.

would not have excused the faults of the district, and since it was admittedly guilty of extensive delays, its claim for damages for delay was properly rejected under the rules previously stated.

22 Cal. Rptr. at 591-94.

9 This opinion disturbed some state agencies that administer construction contracts, which commonly involve delays in performance. The State Department of Public Works filed an amicus curiae brief in support of the request hy the School District for a hearing in the California Supreme Court in which it stated that in 1961, 543 highway construction contracts were completed and accepted. Liquidated damages were assessed in 62 of these. Brief for the Dept. of Public Works of the State of California as Amicus Curiae, pp. 2-3, Kiewit v. Pasadena School Dist., 59 A.C. 253, 379 P.2d 18, 28 Cal. Rptr. 714 (1963). These state agencies feared they would no longer be able to enforce their provisions for liquidating damages for delay, id. at 14-16, and actual damages are often difficult to prove. In this connection, however, it nnight be noted that the method of computing damages by rental value is often available but frequently overlooked. 5 CORBIN, CONTRACTS \& 1092 (1951).

${ }^{10}$ See cases cited in Sweet, Owner-Architect-Contractor: Another Eternal Triangle, 47 CATIF. L. REv. 645 n.18 (1959).

11 See generally Annots., 65 A.L.R.2d 1278 (1959); 1 A.L.R.2d 338 (1948).

1245 Cal. App. 2d 334, 114 P.2d 65 (1941).

13 Brief for Appellant, p. 79, Brief for Respondent, pp.49-54, Kiewit v. Pasadena School Dist., 22 Cal. Rptr. 589 (1962). 
To accomplish this, the court breathed life into a previously moribund portion of Section 1511(1) of the California Civil Code, ${ }^{14}$ which excuses delay in performance caused by "the act of the creditor, or by operation of law, even though there may have been a stipulation that this shall not be an excuse."15 Holding that an owner in a building contract is a creditor within the meaning of section 1511(1), the court stated that "a provision in an agreement that a contractor is not to be excused for late completion caused by the owner is rendered inoperative by the statute." 16 To this point the statement of the court can be supported by the statute. Section 1511 can be interpreted to preclude one party from assuming, by contract, the risk of delay caused by the other party. But the court used section 1511 to cut a wider swath; stating:

A provision in a contract which would require the contractor to make an application for an extension of time before he may be excused for delay caused by the owener's conduct would obviously constitute a substantial limitation on the policy declared in $\S 1511 .^{17}$

This is the heart of the Kiererit decision. The statute does not proscribe "substantial limitations" but uses the language, "a provision that this shall not be an excuse." The provision for conditioning the extension upon timely written notice does not coinpel the contractor to assume the risk that he will be delayed by the owner. It merely creates a procedural condition precedent to the right to claim an extension. In the sense that any right that is conditioned is limited, of course, the condition of notice limits the right to obtain an extension. But such a sensible, standard requirement should not be considered a "substantial limitation" even if the statute had been framed in such a manner. Yet the court held that the statute compels nonenforcement of this contractually created condition, at least where the owner caused the delay. The notice question thus removed from consideration, the court sustained the trial court finding that the delays were caused by the School District and affirmed for Kiewit.

What is the background of the portion of section 1511 used to frustrate notice conditions? The statutory language crucial to the Kieverit decision

14 In its entirety $\$ 1511(1)$ reads:

The want of performance of an obligation, or an offer of performance, in whole or in part, or any delay therein, is excused by the following causes, to the extent to which they operate:

1. When such performance or offer is prevented or delayed by the act of the creditor, or by the operation of law, even though there may have been a stipulation that this shall not be an excuse.

1559 A.C. at 256,379 P.2d at $20,28 \mathrm{Cal}$. Rptr. at 716 (Emphasis by court).

10 Id. at 256,370 P.2d at 20,28 Cal. Rptr. at 716.

17 Ibid. (Emphasis added.) 
was not based upon case precedent as were most of the Field Code sections. ${ }^{18}$ Until Kiewit, it had never been applied in California. ${ }^{10}$ Its one use

18 Section 1511 is derived from $\$ 727$ of the proposed New York Code of 1865 . In Field's final report (the ninth) various phrases of the section were marked with footnotes citing English and early New York cases. There is no footnote to the phrase "even though there may have been a stipulation that this shall not be an excuse." CrvIl CODE OF THE STATE OF NEW

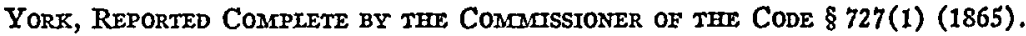

The California Annotations of the Code of 1872, also contained case citations. The only cases cited, however, were those that had been cited by the New York Code Commissioners. In sum, there was no case authority for the crucial code section. LINDIEY, CarIForana Code Commentartes (1872).

One possible explanation for the phrase is that Field created it from a juxtaposition of several articles of the French Code. Field went to Europe in 1836-1837 to study "the codes of England, France and other countries." FIExD, Record of THE LIFE OF DAvid DuDLEY FIEID $40-41$ (1931). There are a number of references in the Code Comments of the Code Napoleon and the Louisiana Code. E.g., Civin Code of the State of New York, Reported Comptete BY THE COAMIISSIONERS OF THE CODE $\$ 8$ 753-54 (1865).

The corresponding sections of the French Code were articles 1147 and 1148 of the Civil Code passed February 7, 1804 and promulgated on February 17, 1804. They provided:

Art. 1147. A debtor shall be ordered to pay damages, if there is occasion therefor, either on account of non-performance of the obligation or on account of delay in performing it, whenever he does not establish that the non-performance is due to a foreign cause which cannot be charged to him, provided moreover there is no bad faith on his part.

Art. 1148. No daunages shall be due when the debtor has been prevented froin giving or doing what he had bound himself to do, or what he was not to do, owing to superior force or an inevitable event.

Code Crvil (Fr. rev. ed. Cachard 1930).

These sections have various cross references. For example, article 1772 deals with "Contracts of Letting." It states that "a lessee may be held responsible for accidents, by an express stipulation." Article 1303 is part of Chapter V, which deals with "Extinction of Obligations." It states that:

When a definite and specific thing forming the subject matter of an obligation is destroyed or can no longer be used in trade (1) or is lost, in such a way that its existence is absolutely unknown, the obligation ceases if the thing has been destroycd or lost not owing to the fault of the debtor ... [or] if he has not assumed the risk of accidents....

Articles $1147-48$ set up a general rule excusing an obligation if the debtor is prevented from performing. Various other sections specified that risks of loss or destruction of property can be assumed by the obligor. Perhaps combining these articles led Field to permit one party by contract to assume only those risks relating to "acts of God" as opposed to acts of the other party or operation of law. Section 1511(2) of the Cahifornia Civil Code permits the debtor to assume the risk of prevention due to "an irresistable, superhuman cause," while subsection (1) dcaling with "operation of law" or act of the creditor does not permit contractual assumption of this risk.

${ }^{19}$ In People v. Meyers, 215 Cal. 115, 8 P.2d 837 (1932), Alaineda County brought an action against a bail bond surety. The court held for the defendant surety because San Francisco County had held the defendant, then let her go and ordered her to leave the state. The court stated: "The defense of prevention by the act of the creditor cannot be waived, even expressly, in the contract." Id. at 119, 8 P.2d at 839. The court went on to state that this was not a risk assumed by the surety.

Since the assumption of risk was not in the bail bond contract, the remarks of the court were dicta. This is the only case in which the crucial portion of 81511 relied upon by the Kiezit decision was cited in Cahforma. 
in all the other Field Code states did not involve a condition of notice. ${ }^{20}$ Nevertheless, it was the cornerstone of an opinion emasculating a universal construction contract provision.

Conditions of notice serve an extremely useful function in building contract administration. If the claim for extension is made during performance of the contract, a factual determination of whether the claim is justified, and if so, the amount of the extension to be awarded, is ordinarily made by the architect or engineer. ${ }^{21}$ Frequently there is a provision that permits the architect's decision to be submitted to arbitration. ${ }^{22}$ Notice of an intention to claim an extension will set this fact-finding process into motion. Investigation can be made while the evidence is fresh. The ultimate fact determination will be made by persons selected by the parties on the basis of their technical skill, by a process that is expected to be quick, informal, and mexpensive. When notice is not given, the claim is often made long after completion of the contract, when testimony may be clouded by what the contractor wishes had happened and by documentary evidence that is fragmentary or absent. Some contractors use the post-completion claim to avoid arbitration, hoping a court will be a more sympathetic forum.

Furthermore, without notice the owner may not know of the delay and of its effect on the contractor's performance. The asserted delays may be caused by persons for whose conduct the owner is responsible, such as the architect, the enginer, or other contractors. ${ }^{23}$ Without notice, the activities of these persons may not come to the owner's attention. Delays are quite common in construction jobs and often do not have any appreciable effect upon the contractor's performance or the cost of his performance. ${ }^{24}$ Notice gives information to the owner that permits him to take quick corrective action to eliminate the cause of delay. Also, the owner may want to keep more detailed time records if he knows a claim will be made. ${ }^{25}$

20 Pioneer Eng'r Works v. McConnell, 123 Mont. 171, 212 P.2d 641 (1949).

21 Amirrican Institute of Architects, Standard Contract, art. 39, Doc. No. A-201 (1961).

22 Id. at art. 40.

23 Id. at art. 18.

24 He may have other jobs on which he can use his men and equipment. Performance schedules are often loose and have sufficient flexibility to allow for short delays.

25 The amicus brief of the State Department of Public Works stated:

Disregard by the Court of this vital contract provision robbed the appellant [School District] of the opportunity to compile information which would have enabled the school district to establish the amount of delay in each of these instances. It is obvious that it does not behoove an owner to keep detailed time records where the contractor, during the job, is not asking for an extension of time. The very function of this provision is to alert the owner to the claim of delay. The owner is then in a position to take such steps to remove the delay or keep such records as will enable the trier of fact to ascertain the delay.

Brief for the Dept. of Pub. Works, supra note 9 at 17. 
Finally, prompt notice tends to show that the claim of delay has merit. ${ }^{20}$ As a rule contractors do not hesitate to complain when their performance is affected by the owner. After a contractor has been assessed liquidated damages for late performance, a claim that his delay was caused by the owner may seem to be an easy way to recover amounts withheld for unexcused delay when, in fact, the late performance may have been caused by poor estimates or inefficient performance.

Generally, conditions of notice are given effect by the courts. ${ }^{27}$ There may be situations where strict enforcement can cause injustice. The owner may be aware of the delay, the reasons for it, and the effect it is having upon the contractor. There may have been a prior course of conduct that has led the contractor to reasonably believe that the written claim need not be asserted. Where needed, courts have used the theories of waiver, estoppel, and impossibility to excuse the condition..$^{28}$ In rare situations the condition may be excused if enforcement would compel extreme forfeiture. ${ }^{29}$ Adequate legal theories exist to prevent injustice. It was not necessary in Kienrit to destroy the notice provision to achieve the result sought by the court.

What effect will this decision have upon other notice conditions in building contracts? $?^{30}$ Could it affect "no damage" clauses in building contracts? ${ }^{31}$ Will it be used to avoid conditions of notice in other types of

26 This consideration was part of the basis for section 49 of the Uniform Sales Act, which conditions certain warranties upon the buyer notifying the seller within a reasonable tine after the buyer knows or should know of the breach. Cf. UnIForm Commerctal Code $\$ 2-607$ (3). In Wojciuk v. United States Rubber Co., CCH Products LIABIIITY Rep. $\| 5085$ (Wis. Aug. 6, 1963), the court stated:

A valid argument can be made, however, that it is important to guard against personal injury claims which are generated by afterthought as to warranties nuade, and that a person who honestly feels that his imjury was caused by a breach of warranty is very likely to assert his claim promptly.

Also, section 49 was meant to reduce the "blackmail" counterclaims of breach of warranty when the seller sues for the contract price. Notices of this sort for similar reasons are generally required to perfect claims for workman's compensation. 2 LARSON, WORKMAN's COMPENSATION LAW 78 (1961).

27 3A CoRBn, Contracts $\$ 727$ (1960).

28 Id. at $\$ 756$ (waiver); 6 CORBIr, ConTrACTs $\$ 1362$ (1962) (impossibility). Impossibility usually applies to the condition that an insured give a notice within a specified or reasonable time to the insurer. See Burbank v. Nat'l Cas. Co., 43 Cal. App.2d 773, 111 P.2d 740 (1941).

29 Restatement, Contracts $\$ 302$ (1932). This is applied only if the condition sought to be excused does not constitute an "essential part of the exchange." Usually, these are "technical" conditions.

30 The Standard AIA Contract requires the contractor to give a notice if he considers a direction given to him would require extra work. ANAERICAN INSTITUTE OF ARCBHTECTs, op. cil. supra note 21 , at art. 16 . It also requires that a written claim for damages be made within a reasonable time from first observance of the damage. Id., at art. 31 .

31 It is common in public contracts and becoming more common in private building contracts to restrict the contractor to extensions of time for delays caused by the owner and not 
contracts ? $^{32}$ The answers will have to wait until more cases are decided, and the period of uncertainty and litigation is hikely to prove troublesome.

To sum up, on the surface the holding appears sensible. It is difficult to criticize a result that refuses to permit the School District to keep money as damages when it has caused the delay. The court, however, refused to confront two difficult but far from insurmountable legal questions. Instead it resurrected a statute whose application is questionable at best. ${ }^{33}$

permit him an action for delay damages. Such clauses are generally upheld. Annot., 10 A.L.R.2d 803-04 (1950). See Maurice L. Bein v. Housing Authority, 157 Cal. App. 2d 670, 321 P.2d 753 (1958), where a no damage clause was upheld at least by implication. If $\S 1511$ (1) precludes the owner from placing the risk of his delays upon the contractor, can the owner by contract restrict the contractor to an extension of time? A careful reading of $\S 1511$ should preclude a successful attack upon "no damage" clauses. The statute only deals with excusing the contractor's failure to perform on time caused by the other party's delay. It does not deal with affirmative action by the contractor for owner's breach.

32 Leases abound with notice conditions. Also, contracts in which delay in performance is likely often require a notice for obtaining an extension of time. For example the following is a clause taken froin a contract for the construction of a heavy piece of machinery:

Seller, in order to claim any extension of time for delivery of the ... . equipment or for the erection of the ... equipment for excusable delays, must promptly advise purchaser in writing of any excusable delay which is affecting Seller's performance. Such notice must be given by Seller within ten (10) days of the start of the delay or the delay will not be excusable.

In such a contract there is the additional factor that the buyer wants to know of delays in order to make adjustunents in his plant. Normally, if such delays are caused by the buyer, he knows of them. But giving notice still serves the function of permitting the buyer to eliminate the cause of the delay or at least mitigate the damages.

Finally, it is almost standard to provide for curing provisions in contracts. Under such provisions, the innocent party must give the breaching party notice of the breach and the innocent party's intention to terminate in order to permit the breaching party to cure the default.

33 There was a line of cases that could have been used by the court in applying a waiver doctrine. Frequently, written notice is required by statute as a condition precedent to a claim for personal injury agamst a public body. In 1944 the Califorma Supreme Court beld the public body could be estopped from asserting the lack of notice. Farrell v. County of Placer, 23 Cal. 2d 624, 145 P.2d 570 (1944). An unbroken line of cases in Cabifornia has followed the Farrell case. See. e.g., Bruce v. Jefferson Union High School Dist., 210 Cal. App. 2d 632, 26 Cal. Rptr. 762 (1962): Peck v. City of Modesto, 181 Cal. App. 2d 465, 5 Cal. Rptr. 482 (1960); Dettamanti v. Loinpoc Union School Dist., 143 Cal. App. 2d 715, 300 P.2d 78 (1956).

It is true that it may be easier to employ estoppel when the plaintiff is the victim of an injury and often a person of hittle business experience than when the damage is pecuniary and where the person asserting estoppel is an experienced businessman. This might be a good reason not to use estoppel in a Kiewit type case. On the other hand, it should be casier to find estoppel where the condition being excused is created by contract rather than by statute as in the personal mjury cases. In any event, the analogy was available. If the equities were strong enough to gut a sensible contract provision, then they were strong enough to reason by analogy from the personal injury cases.

The Gogo case was not an insurmountable problem. The court could have clarified Gogo without great difficulty by holding the nonapportionment rule to apply only where there is no express provision for apportioning damages. Indeed, in Kiewit the court did in fact clear up the ambiguity of Gogo by mentioning in passing that the rule would have no application where there was an extension provision. The court did not mention Gogo and merely cited Williston. 59 A.C. at $25 \%, 379$ P.2d at 20-21, $28 \mathrm{Cal}$. Rptr. at 716-17. 
Unlike most unfortunate contract appellate decisions, this one cannot be circumvented by private drafting. It is a positive rule of law that unnecessarily limits freedom of contract. Judicial legislating by the highest court of a state should be done with great care and only after giving considerable thought to the impact of the decision. The court in the Kiewit decision gave little evidence that its thought went beyond doing justice to the parties.

Kiewit dealt ouly with delays caused by the owner. Perhaps the result will not be extended beyond this poimt. ${ }^{34}$ But even this result is most undesirable. The underpinnings of the Kiewit decision should be removed. That portion of section 1511(1) rehed upon by the court should be repealed. ${ }^{35}$

34 There was some feeling among state officials that the court left an escape hatch by the way in which it handled Roberts v. Sec. Trust \& Sav. Bank, 196 Cal. 557, 238 Pac. 673 (1925). The court stated that Roberts could be distinguished hecause it involved a factual determination by the architect that the contractor was at fault. 59 A.C. at 256,379 P.2d at 20, 28 Cal. Rptr. at 716. The difficulty with this is that if a factual determination is made by the architect or engineer, generally notice has been given or the owner was aware of the delay and its effect upon the contractor. The real problem is the claim made after the contract performance has been completed. It is doubtful that this is much of an escape hatch.

There is a method for limiting the impact of the case. Section 1511 deals with excusing performance of one party because the other party interfered or prevented it. Applied to the Kiewit case this meant that the contractor's obligation to finish on time was excused and thus he could not be assessed hiquidated damages. If there is a claim of damages by the contractor, as distinguished from a request for an extension of time, it can be argued that $\S 1511$ does not apply. The code section deals only with excuse of condition. In such a situation the owner could still assert that the contractor did not give notice of the claim and is precluded from recovering damages because the notice conditioned the right to recover damages for the other party's breach rather than excusing the performance of the contractor.

If this distinction between excuse of performance and breach is kept in mind, some of the broader impact of the decision can be reduced. But there is a real danger that courts will use the spirit of the Kiewit case to eliminate conditions of notice where it seems just to do so.

35 No harn would be done by amending the statute in the manner suggested. The law would still excuse the condition if it were prevented or delayed by the other party. The only effect would be to permit one party to assume the risk that his perfornance would he delayed or made more difficult or expensive by the act of the other party. Without mentioning $\S 1511$ one California case held this could he done hy contract. Kline v. Johnson, 121 Cal. App. $2 d$ Supp. 851, 263 P.2d 494 (Cal. Super. Ct. 1953). This assumption of risk is permitted at common law. Restatement, Contracts $\$ 295$ (b) (1932); 3A Corbin, Contracts $\$ 767$ (1960); 6 Corbin, Contracts $\$ 1264$ (1962). 